\title{
Use of new psychoactive substances among the general population in Croatia: Patterns of use and sociodemographic characteristics of users
}

\author{
Renata Glavak Tkalić \\ Institute of Social Sciences Ivo Pilar, Zagreb Croatia
}

\begin{abstract}
The aim of this study is to provide information on the prevalence of new psychoactive substances (NPS) use among the general population in Croatia, patterns of NPS use and characteristics of NPS users. The data on NPS use, patterns of NPS use, licit and illicit substance use, and general information on participants, were gathered by empirical research on a nationally representative sample of Croatian adults aged 15-64 years ( $N=4992$ ). Lifetime prevalence of NPS use in Croatia was $2.7 \%$, and last year $1.3 \%$. The most common form of NPS used was herbal smoking mixtures (76.2\%), and most users have been given or bought NPS from a friend (69\%). Most NPS users were male (75.4\%), young adults between 15-34 years (75.8\%), single (73.1\%), had a high school education (68\%), and currently were either high school or university students (39.4\%), employed (33.1\%) or self-employed (7.2\%). NPS users have reported very high prevalence of use of licit (79.5\% tobacco, $89.9 \%$ alcohol, and $57.5 \%$ had an episode of binge drinking) and illicit substances (55.6\%, most commonly cannabis) over the month preceding the survey. High lifetime prevalence of illicit drug use was found for amphetamines (42.5\%), ecstasy (35.4\%), LSD (24.6\%), and cocaine (23.9\%).

In Croatia, the lifetime prevalence of NPS use is relatively low among the general population. Most NPS users are single young males who exhibit patterns of polydrug use. Due to serious risks associated with NPS use, prevention should be one of the national drug policy priorities.
\end{abstract}

Key words: new psychoactive substances, prevalence, patterns of use, general population, Croatia

Copyright @ 2018 KBCSM, Zagreb

e-mail: alcoholism.kbcsm@gmail.com•www.http://apr.kbcsm.hr

\section{Introduction}

A new psychoactive substance (NPS) is defined as "a new narcotic or psychotropic drug, in pure form or in preparation, that is not controlled by the United Nations drug

Correspondence to: Renata Glavak Tkalić

Institute of Social Sciences Ivo Pilar, Marulićev trg 19/1, Zagreb,

Croatia

Phone: +0038514886814

E-mail: renata.glavak.tkalic@pilar.hr conventions, but which may pose a public health threat comparable to that posed by substances listed in these conventions" [1]. NPS are rapidly evolving and varied, easily accessible and inexpensive unregulated psychoactive substances that have become newly available on the market, and are not detected by standard toxicology screens. NPS that became popular over time are those offering acceptable alternatives to available controlled 
drugs [2]. There is a variety of NPS that mimic the effects of established substances - cannabinoids, stimulants, hallucinogens and opioids, but the pharmacology and acute or chronic toxicity of these substances are largely unknown [3-5]. NPS are based on mixtures of chemicals and pharmacological agents in unknown concentrations, making it difficult to specify the psychoactive ingredients responsible for their effects [6]. NPS are often called 'legal highs', which is a misleading term, since 'legal' implies a level of safety, but there is no quality control with NPS [7]. The majority of NPS products are smoking mixtures containing synthetic cannabinoids, and they are sold as legal replacements to cannabis. In many cases, an unknown combination of potentially toxic chemicals are sprayed on plant material and sold as an alternative to marijuana [8].

NPS may potentially cause a variety of serious health and life-threatening consequences, with symptoms including agitation, hallucinations, psychosis, and violent behaviors [3]. Synthetic cannabinoids have been associated with strokes, liver and kidney damage, and there are concerns that the use of these types of NPS may worsen psychiatric symptoms $[9,10]$. Synthetic cathinones have been associated with needle injections, compulsive use and social harms [11]. The long-term neuropsychiatric consequences of NPS exposure are not known [3]. Use of NPS has been associated with acute poisonings and deaths [11].

The emergence of NPS has been reported in many parts of the world, and their number is expected to rise [12]. Until the mid-2000s only a small number of NPS, called 'designer drugs' were reported each year in Europe, and were mostly sold on the illicit drug market [5]. The emergence of 'legal highs' was largely responsible for the extensive growth in the market in recent years, and there has been an increase in the number, type and availability of NPS in Europe [1]. NPS are usually sold openly, packaged and promoted as 'natural' or 'legal' products, in specialized 'smart shops' and online shops, under different marketing names, such as Galaxy, Rainbow, Spice [13]. In 2013, the European Monitoring Centre for Drugs and Drug Addiction (EMCDDA) identified 651 web-based shops selling 'legal highs' or 'research chemicals' to EU consumers [14]. NPS may also be sold on darknet markets and on the illicit markets (by street-level drug dealers), under their own name or falsely as illicit drugs like heroin, cocaine, ecstasy etc. [11].

Since 1997 a three-level mechanism has been in use in Europe for identifying and responding to the risks of NPS: an early-warning system (EWS), risk assessment of new substances identified as potential threats, and political decisions enacted through national legislation [1]. This mechanism has allowed the EU to early recognize the emergence of the NPS, and more than 620 substances are currently being monitored by the EMCDDA, with 66 new substances detected for the first time in 2015 [11]. This includes synthetic cannabinoids, synthetic cathinones, phenethylamines, tryptamines, piperazines, and a range of other substances (such as medicines and their derivatives) that do not fit into any other of chemical classes [15]. In 2007, the Office for Combating Drug Abuse of the Government of the Republic of Croatia initiated the creation of the Early Warning System (EWS) on NPS in Croatia, which is now a full member of the EU EWS [16]. In 2013, the internet database of NPS was developed in Croatia, with the goal to monitor the dynamics of EWS for NPS in Croatia and across the EU [17].

The number and diversity of NPS reported in Europe in recent years represent a ma- 
jor challenge for the European policymakers [13]. Products containing NPS are often given deceptive names and labeled 'not for human consumption' to elude detection and the laws prohibiting the sale and use of psychoactive drugs [3]. Additionally, their availability is rapidly increasing. The traditional response of assessing the risk to public health and adding a NPS to the national list of controlled substances was a measure sufficient when discovery of a new 'drug' was a relatively rare event, but an increasing number of NPS being reported to the EU EWS (e.g. at a rate of one per week in 2016) requires implementation of additional appropriate measures [11]. The problem is that drug law must clearly list all substances under its control [13]. Over the recent years, four distinct policy challenges have been identified, because: substances are new and there is no evidence of their risks to public health; updating the law takes time; definitions that control many substances are too broad and vague for criminal legislation to be unambiguously applied; and new tests required by the law before a substance may be added to the list, require technical and financial resources that are not always available (13). Moreover, most NPS tend to be replaced as soon as control measures detect a new psychoactive substance, which represents a special challenge for the intervention measures associated with using psychoactive substances [6]. Some countries, including Croatia, have chosen to extend the coverage of existing drug laws by listing defined groups of substances, rather than individual drugs [13]. In Croatia in 2016 new generic List of Drugs, Psychotropic Substances and Plants that can be used in the production of drugs was adopted, which includes several groups of substances defined by generic descriptions of chemical structure [18].
Little is known about the prevalence of use of NPS in Croatia as well as in other European countries, especially among the general population. The results of the 2014 Flash Eurobarometer, a survey of 13,128 young adults aged 15-24 conducted in the 28 Member States of the European Union, showed that $8 \%$ of respondents had used a NPS at least once, and 3\% reported using them in the last year. Last year prevalence of NPS use was (not including ketamine and GHB) among young people aged 15-24 ranged from $9.7 \%$ in Ireland to $0.2 \%$ in Portugal [4]. In the Croatian subsample $(\mathrm{N}=500)$ it was found that $7 \%$ of respondents had used a NPS at least once, and $2 \%$ used them in the last year [19]. Most respondents who had used NPS in the last year either bought them from, or were given them by, a friend (68\% EU average, $80 \%$ in Croatia), and the rest mostly bought them from a drug dealer (27\% EU average, 29\% in Croatia), or purchased them from a specialized shop $(10 \%$ EU average, $7 \%$ in Croatia). Most respondents used NPS with friends (60\% EU average, 67\% in Croatia), or during a party or an event e.g. music festival, clubbing (65\% EU average, $37 \%$ in Croatia), and a fewer alone, privately (15\% EU average, $9 \%$ in Croatia). The European School Survey Project on Alcohol and Other Drugs [20] which collects comparable data on substance use among students aged 15-16 years throughout Europe, showed that the average of lifetime experience with NPS was $4 \%$, with the highest rates in Estonia and Poland (10\% each), and the lowest in Belgium (Flanders), Denmark, Finland, Norway and Portugal, with rates of $1 \%$. In Croatia, lifetime prevalence of NPS use among students was above average, $7 \%$, and the last year prevalence was $6 \%$. Gender differences within ESPAD countries were generally small, with the average lifetime prevalence of $5 \%$ among 
boys and $4 \%$ among girls. There were no gender differences in the Croatian sample [20].

Additional data on NPS are available through several other indicators: number of seizures by law enforcement, number of newly identified psychoactive substances, database of NPS, monitoring internet and 'smart shops', data from treatment demand, and data from harm reduction programs [1,16]. According to the reports associated with removal of NPS from the market, a seven-fold increase in the number of seizures was reported across Europe in the 20082013 period [1]. In 2015, the EU EWS was notified of almost 80,000 seizure cases of NPS, amounting to 4.3 tones. During the same year, synthetic cannabinoids, sold as legal replacements for cannabis, and synthetic cathinones, sold as legal replacements for stimulants such as amphetamine and MDMA, accounted for over $60 \%$ of the total number of seizure cases [11]. China and India (to a lesser extent) have been reported by EU Member States as the main source of NPS delivered to Europe, where they are processed, packaged and sold [5,11].

However, beyond these statistics, available data about NPS are limited. The prevalence, trends and patterns in their use are still very much unknown. The growth of NPS market poses a major threat to public health, which emphasizes the importance of monitoring the use of NPS in Croatia. Therefore, the aim of this paper is to present the data on the prevalence of NPS use among the general population of the Republic of Croatia and to determine the key characteristics of NPS users (user profile).

\section{Methods}

The target population in this study were residents of the Republic of Croatia aged between 15 and 64 years, living in private house-

Alcoholism and Psychiatry Research 2018;54:5-20 holds. The planned sample was divided into two subsamples. In the population sample aged 15-64, the target sample size was 4,000 completed interviews. An additional sample of 1,000 respondents aged 15-34 was oversampled to increase the statistical power and to get more robust sample of young adults who are more prone to illicit drug use. As a sample frame list of house numbers covering the territory of Croatia was used, and 11,410 addresses were randomly selected. Out of a total number of addresses 8,919 were valid, and the sample ended up in 5,010 respondents who participated in the study (which resulted in a $56.2 \%$ response rate). The responses of 4,992 respondents who properly completed questionnaires were analysed. Since minors (aged 15-17) were also included in the study, recommendations of the Croatian Psychological Chamber on including minors in the research were followed, and parents were asked to grant permission for interviewing their children. The research obtained ethical approval from the Ivo Pilar Institute Ethics Committee. The data was weighted to represent the distribution of birth cohort and gender in the general population of Croatia. The main characteristics of the weighted sample are presented in Table 1.

\section{Instruments}

\section{Prevalence of licit and illicit substance}

use. The data on lifetime (LTP), last year (LYP) and last month prevalence (LMP) of substance use were collected by means of the Croatian translation of the European Model Questionnaire (EMQ) (21). ${ }^{1}$ EMQ is the stan-

1 The term "prevalence" refers to the proportion of population who reported taking substance over a particular period of time. Lifetime prevalence (LTP) refers to the proportion of the respondents in a sample who reported ever using a particular substance, last year prevalence (LYP) refers to the proportion of the respondents in a sample who reported using a particular substance in the year prior to the survey, and last month prevalence (LMP) refers to the proportion of the respondents in a sample who reported using a particular substance during the 30 days prior to the survey (22). 
Table 1. Sociodemographic characteristics of the respondents (weighted sample)

\begin{tabular}{|c|c|c|}
\hline $\mathrm{N}$ & & 4992 \\
\hline \multirow[t]{2}{*}{ Gender } & Male & 50.0 \\
\hline & Female & 50.0 \\
\hline \multirow[t]{5}{*}{ Age } & $15-24$ & 17.6 \\
\hline & $25-34$ & 20.3 \\
\hline & $35-44$ & 19.9 \\
\hline & $45-54$ & 21.8 \\
\hline & $55-64$ & 20.4 \\
\hline \multirow[t]{5}{*}{ Marital status } & Married & 52.5 \\
\hline & Single & 35.5 \\
\hline & Common law marriage & 3.3 \\
\hline & Divorced & 4.7 \\
\hline & Widowed & 4.0 \\
\hline \multirow[t]{8}{*}{ Level of education } & Non & 1.7 \\
\hline & Primary school & 9.8 \\
\hline & Vocational schools lasting 2-3 years & 19.0 \\
\hline & Secondary school lasting 4 years & 42.3 \\
\hline & Non-university college & 8.9 \\
\hline & Bachelor's degree & 4.1 \\
\hline & Master's degree or equivalent & 13.5 \\
\hline & Postgraduate study & 0.9 \\
\hline \multirow[t]{8}{*}{ Economic activity } & Employed & 45.8 \\
\hline & Self-employed & 5.0 \\
\hline & High school/university student & 14.8 \\
\hline & Housewife & 5.2 \\
\hline & Retired & 12.7 \\
\hline & Temporarily employed & 3.4 \\
\hline & Unemployed & 11.1 \\
\hline & Other & 2.0 \\
\hline
\end{tabular}

dard model for national surveys on substance use in a population, and allows the international comparability of the epidemiological status in the field of substance use [22]. The questions used for the purpose of this study, asked about lifetime, last year and last month prevalence of tobacco, alcohol, cannabis, ecstasy, amphetamines, cocaine, heroin, and LSD use. Additionally, the questions covered the frequency of alcohol and cannabis use in the last 30 days (number of days having taken alcohol/cannabis in the last 30 days), 
as well as the average number of cigarettes smoked daily in the last 30 days. Binge drinking was also assessed, defined as a frequency of drinking 6 glasses or more of an alcoholic drink in succession on the same occasion.

Prevalence and patterns of NPS use. Self-reported data on lifetime and last year prevalence of NPS use were gathered by means of the Croatian translation of the EMQ Module for monitoring use of NPS in general adult population [21]. The following statement was presented to respondents at the beginning of the survey: „New substances that imitate the effects of illicit drugs (such as cannabis, ecstasy, cocaine, etc.) may now be sometimes available. They are sometimes called ,new drugs“, and can come in different form, for example - herbal mixtures, powders, crystals or tablets. Have you ever used such substances? ". Responses on physical form of NPS (herbal smoking mixtures; powder, crystal or tablets; liquids, and other), and source where NPS is usually acquired from (been given or bought them from a friend; bought at a specialized shop; from the Internet; from a drug dealer, and other) were also assessed.

General Information on Participants Questionnaire. For the purpose of this research, a questionnaire was constructed in order to obtain personal information about participants, including gender and age, and their socio-economic status (marital status, level of education, and economic activity).

\section{Procedure}

The data was gathered by empirical household survey, using face-to-face interviews. The interviewers were carefully instructed and prepared for suitable survey introduction to potential respondents espe- cially about confidentiality in order to solicit their participation in the survey. The interviewers paid special attention to convince the respondents that the survey is voluntary, that their data will be collected anonymously and kept in strict confidentiality, and only used as a summary data. Due to the sensitivity of the topic, the respondents were allowed to fill out the questionnaire themselves, and the interviewer assisted if needed. After completing the questionnaire, in order to additionally confirm anonymity, respondents were asked to put the completed questionnaire in an unmarked envelope, seal it and mix it with other unmarked envelopes. The interviewing took about 20 minutes.

\section{Results}

\section{Prevalence of NPS use, physical forms and sources of NPS acquisition}

The use of NPS at least once in their lifetime was reported by $2.7 \%$ of respondents aged 15-64 (Table 2) and it was considerably higher for males than females $(4.1 \%$ vs $1.3 \%$ ). As shown in Table 2 , the highest lifetime prevalence was found in the 15-24 age group $(6.9 \%)$, followed by the $25-34$ age group $(4.2 \%)$. The last year prevalence of NPS use of $1.3 \%$ was reported by the respondents aged 15-64 (Table 2). Among NPS users in the age group 15-24 who reported the highest lifetime prevalence and the highest last year prevalence, the majority were young males $(9.8 \%$ and $4.8 \%$, respectively).

The NPS users reported herbal smoking mixtures as the most common form of NPS they used in the year prior to the survey (76.2\%). Other NPS commonly used forms were powder, crystals or tablets (19.5\%), liq- 
Table 2. Lifetime (LTP) and last year prevalence (LYP) of NPS use among general population $(\mathrm{N}=4992)$, by age groups and gender

\begin{tabular}{|c|c|c|c|}
\hline \multirow{2}{*}{ LTP of NPS use } & \multirow{2}{*}{ Total } & \multicolumn{2}{|c|}{ Gender } \\
\hline & & Males & Females \\
\hline 15 - 64 years (whole sample) & 2.7 & 4.1 & 1.3 \\
\hline $15-24$ years & 6.9 & 9.8 & 3.8 \\
\hline $25-34$ years & 4.2 & 6.2 & 2.1 \\
\hline $35-44$ years & 1.8 & 3.4 & 0.2 \\
\hline $45-54$ years & 1.1 & 1.7 & 0.5 \\
\hline $55-64$ years & 0.3 & 0.0 & 0.6 \\
\hline \multicolumn{4}{|l|}{ LYP of NPS use } \\
\hline 15 - 64 years (whole sample) & 1.3 & 1.8 & 0.8 \\
\hline 15 - 24 years & 3.6 & 4.8 & 2.3 \\
\hline 25 - 34 years & 1.6 & 2.2 & 1.1 \\
\hline $35-44$ years & 0.8 & 1.4 & 0.2 \\
\hline $45-54$ years & 0.4 & 0.7 & 0.2 \\
\hline $55-64$ years & 0.2 & 0.0 & 0.4 \\
\hline
\end{tabular}

uids $(8.3 \%)$ and $12.7 \%$ of NPS were used in some other form (Table 3). Most respondents who reported the NPS use in the last year had been given or bought NPS from a friend (69\%), and $44.3 \%$ of them bought them at a specialized shop ('smart shop'). A smaller proportion of respondents bought them from a drug dealer (19\%) or through/ over the Internet/ from an online store $(6.9 \%)$ (Table 3).

\section{Sociodemographic characteristics of users}

Basic information on respondents who reported NPS use $(\mathrm{N}=133)$ at least once in a lifetime, and their socio-economic status, are presented in Table 4. Among those who used NPS at least once in a lifetime $75.4 \%$ were males, with the average age $\mathrm{M}=28.5$, $\mathrm{SD}=10.7$. The majority of NPS users were young adults, $44.6 \%$ aged between 15 and 24 years, and $31.2 \%$ between 25 and 34 years. Only one out of four respondents was older than 35 years $(24.3 \%)$. Majority of the NPS users in the group 'at least once in the lifetime' were single $(73.1 \%), 10.4 \%$ were married, $9.3 \%$ in a common law marriage, $5.8 \%$ divorced, and $1.5 \%$ widowed. The greatest percentage of respondents $(68 \%)$ reported high school as their highest achieved level of education, $10.9 \%$ had faculty degree or higher, $7.8 \%$ had bachelor's degree, and $8.6 \%$ of respondents indicated primary school as their highest achieved level of education. Most of respondents who used NPS at least once were high school or university students $(39.4 \%)$, employed $(33.1 \%)$ or self-employed (7.2\%), and $10.6 \%$ were unemployed (Table 4). 
Table 3. Physical form of NPS and source where NPS usually acquired from $(\mathrm{N}=133)$

\begin{tabular}{llr}
\hline & & $\%$ \\
\hline Physical form of NPS & Herbal smoking mixtures & 76.2 \\
& Powder, crystal or tablets & 19.5 \\
& Liquids & 8.3 \\
& Other & 12.7 \\
\hline Source where NPS usually acquired & Been given or bought them from a friend & 69 \\
& Bought them from a specialized shop & 44.3 \\
& Bought them from the Internet & 6.9 \\
& Bought them from a drug dealer & 19 \\
& Other & 1.7 \\
\hline
\end{tabular}

Use of licit and illicit drugs among NPS users

NPS users have reported high prevalence of lifetime, last year and last month tobacco use. As many as $79.5 \%$ of NPS users smoked tobacco in the month prior to the survey (Table 5), and most of them reported smoking between 10 and 20 cigarettes per day (34\%) (Table 6). The vast majority of NPS users $(89.9 \%)$ consumed alcohol in the month prior to the survey (Table 5): $12.5 \%$ of them had used alcohol for 20 or more days, and $14.7 \%$ for 10 to 19 days prior to the survey (Table 6). Almost one third of NPS users (31.3\%) drank alcoholic beverages until losing control (binge drinking) once a week and $26.2 \%$ of them did it once a month (Table 6).

Use of illicit drugs at least once in a lifetime was reported by $93.7 \%$ of NPS users, $71.9 \%$ used it in a year prior to the research, and $55.6 \%$ in a month prior to the research (Table 5). Cannabis was the most commonly used illicit drug among NPS users. Lifetime prevalence of cannabis use was very high $(90.7 \%)$, and more than half of NPS users $(53.6 \%)$ used cannabis in the month prior to the research (Table 5). Among those NPS users, $18.2 \%$ used cannabis for 20 or more days during the month prior to the research, $24.9 \%$ used it 10 to 19 days and $15.6 \%$ used it 4 to 9 days in the month prior to the research (Table 6). High lifetime prevalence of illicit drug use was found also for amphetamines $(42.5 \%)$, ecstasy $(35.4 \%)$, LSD $(24.6 \%)$, and cocaine $(23.9 \%)$, while last month prevalence of use of these substances were $8.4 \%, 7 \%$, $2.1 \%$, and $3.5 \%$, respectively (Table 5). Only a relatively low proportion of lifetime use of heroin $(4.8 \%)$ was reported by NPS users (Table 5).

\section{Discussion}

The use of NPS is a potentially serious public health problem, which makes studies in this area of utmost importance. Due to methodological and definitional inconsistencies across countries, estimating the prevalence of NPS use is challenging and the comparison of national estimates may be difficult [4]. However, using the standardized methodology and implementing the EMQ Module for monitoring use of NPS in general adult population, the data obtained in this 
Table 4. Sociodemographic characteristics of NPS users $(\mathrm{N}=133)$

\begin{tabular}{|c|c|c|}
\hline & & $\%$ \\
\hline \multirow[t]{2}{*}{ Gender } & Male & 75.4 \\
\hline & Female & 24.6 \\
\hline \multirow[t]{5}{*}{ Age } & $15-24$ & 44.6 \\
\hline & $25-34$ & 31.2 \\
\hline & $35-44$ & 13.2 \\
\hline & $45-54$ & 8.9 \\
\hline & $55-64$ & 2.2 \\
\hline \multirow[t]{5}{*}{ Marital status } & Married & 10.2 \\
\hline & Single & 71.9 \\
\hline & Common law marriage & 9.1 \\
\hline & Divorced & 5.7 \\
\hline & Widowed & 1.4 \\
\hline \multirow[t]{8}{*}{ Level of education } & Non & 1.5 \\
\hline & Primary school & 8.6 \\
\hline & Vocational schools lasting 2-3 years & 16.8 \\
\hline & Secondary school lasting 4 years & 51.2 \\
\hline & Non-university college & 3.2 \\
\hline & Bachelor's degree & 7.8 \\
\hline & Master's degree or equivalent & 9.3 \\
\hline & Postgraduate study & 1.6 \\
\hline \multirow[t]{8}{*}{ Economic activity } & Employed & 33.1 \\
\hline & Self-employed & 7.2 \\
\hline & High school/university student & 39.4 \\
\hline & Housewife & 1.4 \\
\hline & Retired & 1.8 \\
\hline & Temporarily employed & 6.4 \\
\hline & Unemployed & 10.6 \\
\hline & Other & 0 \\
\hline
\end{tabular}

research are comparable to the rates reported for other European countries, as shown in the EMCDDA Country Drug Reports [23]. The lifetime prevalence of NPS use of $2.7 \%$ among the general population in Croatia corresponds to the population-based rates determined in several other European countries for which the recent study data are available: lifetime prevalence of NPS use in Spain was $3.4 \%$, in Germany $2.8 \%$, in Latvia 2.5\%, in Poland 2.2\%, and in Romania 2\%. Higher lifetime prevalence was reported in the Czech 
Table 5. Lifetime, last year and last month prevalence of tobacco, alcohol, and illicit drug use among NPS users $(\%)(\mathrm{N}=133)$

\begin{tabular}{lrrr}
\hline \multirow{2}{*}{ Type of substance } & \multicolumn{3}{c}{$\%$} \\
\cline { 2 - 4 } & LTP & LYP & LMP \\
\hline Tobacco & 92.8 & 82.8 & 79.5 \\
Alcohol & 99.3 & 97.3 & 89.9 \\
Any illicit drug & 93.7 & 71.9 & 55.6 \\
Cannabis & 90.7 & 69.5 & 53.6 \\
Ecstasy & 35.4 & 16.3 & 7.0 \\
Amphetamines & 42.5 & 17.0 & 8.4 \\
Cocaine & 23.9 & 9.5 & 3.5 \\
Heroin & 4.8 & 0 & 0 \\
LSD & 24.6 & 4.5 & 2.1 \\
\hline
\end{tabular}

Table 6. Frequency of using tobacco, alcohol, and cannabis among NPS users who smoked, drunk alcohol, and used cannabis in the month prior to the research

\begin{tabular}{|c|c|c|}
\hline & & $\%$ \\
\hline \multirow{7}{*}{$\begin{array}{l}\text { Number of cigarettes per day in the last } 30 \\
\text { days }(N=106)\end{array}$} & Doesn't smoke every day & 8.6 \\
\hline & 5 or less cigarettes & 6.5 \\
\hline & $5-10$ cigarettes & 13.4 \\
\hline & $10-20$ cigarettes & 34.0 \\
\hline & $20-30$ cigarettes & 18.7 \\
\hline & $30-40$ cigarettes & 7.0 \\
\hline & 40 or more cigarettes & 11.9 \\
\hline \multirow{4}{*}{$\begin{array}{l}\text { Number of days having taken alcohol in the } \\
\text { last } 30 \text { days }(\mathrm{N}=119)\end{array}$} & 20 days or more & 12.5 \\
\hline & $10-19$ days & 14.7 \\
\hline & 4-9 days & 38.6 \\
\hline & 1-3 days & 34.3 \\
\hline \multirow{5}{*}{ Frequency of binge drinking $(\mathrm{N}=132)$} & Daily or almost daily & 2.1 \\
\hline & Once a week & 31.3 \\
\hline & Once a month & 26.2 \\
\hline & Less than once a month & 27.9 \\
\hline & Never & 12.5 \\
\hline \multirow{4}{*}{$\begin{array}{l}\text { Number of days having taken cannabis in } \\
\text { the last } 30 \text { days }(N=70)\end{array}$} & 20 days or more & 18.2 \\
\hline & $10-19$ days & 24.9 \\
\hline & 4-9 days & 15.6 \\
\hline & 1-3 days & 41.4 \\
\hline
\end{tabular}


Republic (5\%) and Ireland (4\%), and lower was reported in Malta (1.4\%), Slovakia (1\%), Slovenia (0.6\%) and Portugal (0.4\%) [23]. Information on the extent to which NPS are used is limited, but knowledge of the situation is improving as more countries incorporate questions about their use in general population surveys [24]. The variability in the prevalence of NPS use seen among countries can be explained by interplay of factors specific for each country, such as different NPS availability and exposure levels, legislation, social attitudes, inadequate access or lack of information on health risks of NPS use, and the differences in socio-economic characteristics across countries. Considering complexity of these factors, further studies are needed to obtain a more detailed picture on how country-specific differences in the background of these factors contribute to between-country differences.

In this research, the highest lifetime prevalence of NPS use of $6.9 \%$ was reported by young adults (15-24 years) which is close to the EU average from the 2014 Flash Eurobarometer, showing that $8 \%$ of young adults reported using NPS in their lifetime [4], and $3 \%$ in the preceding year $(3.6 \%$ in this study). Furthermore, the results of this research are in agreement with the results of the ESPAD project for Croatia [20], indicating lifetime prevalence of NPS use of $7 \%$, and last year prevalence of $6 \%$ among students aged 15 to 16 years.

Herbal smoking mixtures were the most common NPS form used in the year prior to the research $(76.2 \%)$. Other forms reported by the NPS users were powder, crystals or tablets $(19.5 \%)$ and liquids $(8.3 \%)$, whereas $12.7 \%$ used NPS in some other form. This confirms the results of the Global Drug Survey [25] showing herbal smoking mixtures as the most common form of NPS used $(71.6 \%$ in 2015). However, the latest results of this global survey indicate a shift away from herbal smoking mixtures (from $71.6 \%$ in 2015 to $59.5 \%$ in 2017) toward an increase in the use of powders and liquids [25].

The survey results on how NPS were acquired, show that the greatest proportion of users who reported NPS use in the preceding year have been given or bought NPS from a friend (69\%), and $44.3 \%$ of them bought them at a specialized shop ('smart shop'). A smaller proportion of respondents bought them from a drug dealer $(19 \%)$ or over the Internet $(6.9 \%)$. The data of the Global Drug Survey (25) confirm these results - the majority of respondents sourced NPS from friends $(47.1 \%)$, and the next most common source were dealers $(17.3 \%)$.

In this research, respondents who reported that they had ever used NPS ( $=133)$ were mostly males (75.4\%), young adults from $15-24$ years $(44.6 \%)$ or in the $25-34$ age group $(31.2 \%)$, most of them were single $(73.1 \%)$, indicated high school as their highest achieved level of education (68\%), and most of them were high school/university students $(39.4 \%)$ or either employed (33.1\%) or self-employed $(7.2 \%)$. When comparing the demographics between the surveyed sample and the general population of Croatia $(\mathrm{N}=4992)$, NPS users were mostly males, their age was shifted toward younger age (15-34 years), more of them were single, and more of them were high school or university students. Their level of education corresponded to the level of education among the general population.

Use of licit and illicit substances in the survey sample was widespread, with most of respondents reporting that they smoked, drank alcohol and used an illicit drug in the 
month prior to the research $(79.5 \%, 89.9 \%$ and $55.6 \%$ respectively). Among NPS users, the reported last month prevalence of cannabis use was almost three times higher than in the general population (19.4\%) (21). These results confirm the data by Sumnall et al. that for most user groups NPS are one component of polysubstance use, and that 'they are generally added to existing drug repertoires rather than replacing (established) drugs that are already used' [26]. The reactions that NPS are causing when consumed simultaneously with other substances such as alcohol, medicines or illegal drugs are unknown and therefore, their use presents a major health risk [6]. Therefore, it is of critical importance to ensure that users are provided with precise information and made aware of the risks in relation with NPS use, and especially when used in combination with other substances.

The use of NPS is associated with a number of physical and psychological risks [2729], and due to significant prevalence rates of NPS use seen in the general population, especially among young people, prevention of the use of NPS should be one of the current policy priorities. Also, existing effective interventions in reducing drug use and associated health risks should be adapted to incorporate NPS [4]. Due to many unknowns on the use and risks associated with NPS, it is of exceptional importance to continue conducting regular multi-disciplinary studies in this area aimed at identifying the changes in trends and patterns of use, and monitoring characteristics of NPS users. Furthermore, due to constant changes in NPS market and diversity of NPS, potential and current users need be informed about the risks of NPS use, to reduce the damages that may result from such behavior. There is also a growing need to introduce contemporary approaches to counseling and treatment, focusing on the specific needs of NPS users. In order to determine an appropriate treatment plan, physiological and behavioral effects of the varieties of rapidly emerging NPS entering the market should be recognized [6].

There are certain limitations to this study. It is an exploratory study, focused on gaining insights into prevalence and patterns of NPS use in Croatia. Therefore, only descriptive methods were used to present the data aimed at improving our knowledge of this increasing threat. Future studies should use more sophisticated statistical analyses in order to provide correlates and significant predictors of NPS use. Furthermore, the survey collected data only on individuals living in a private household setting and there are other population groups, for which a higher prevalence of NPS might be expected, that were not included in the research (such as individuals in hospitals, prisons, correctional facilities). Additionally, some individuals may not be willing to participate in this type of research. Therefore, the studies on NPS use should employ a combined approach to methodology (quantitative and qualitative studies), and the targeted population should be broadened to include specific risk groups that may be underrepresented in surveys of the general population. Specifically, previous research suggest that NPS are used as a substitute for traditional drugs in nightlife settings [30], and are commonly used among psychonauts people who use substances for exploratory purposes [31], illicit drug users [32,33], and LGTB communities [34]. A further limitation of this study is that self-reported measures were used to assess respondents' substance use, and although the respondents were guaranteed anonymity and confidentiality, giving socially desirable answers cannot be com- 
pletely excluded. Therefore, the prevalence of NPS use should be taken as a lowest reading of level of its use. Future studies should include analyses on prevalence and patterns of use of specific types of NPS (synthetic cannabinoids, synthetic cathinones, etc.) and the use of drugs that are not legally classed as NPS but have a history of recreational use (e.g. ketamine) [4]. Furthermore, attitudes and opinions on NPS use, as well as risk perception of NPS use should be assessed, in the same way as assessments for traditional illicit drugs are performed in the general pop-

\section{References}

1. European Monitoring Centre for Drugs and Drug Addiction. New psychoactive substances in Europe: An update from the EU Early Warning System. Luxembourg: Publications Office of the European Union; 2015.

2. Hughes B, Griffiths P. Regulatory approaches to new psychoactive substances (NPS) in the European Union. Addiction. 2014;109:1591-3.

3. Baumann MH, Volkow ND. Abuse of new psychoactive substances: Threats and solutions. Neuropsychopharmacology. 2016;41:663-5.

4. European Monitoring Centre for Drugs and Drug Addiction. Health responses to new psychoactive substances. Luxembourg: Publications Office of the European Union; 2016.

5. Griffiths P, Evans-Brown M, Sedefov R. Getting up to speed with the public health and regulatory challenges posed by new psychoactive substances in the information age. Addiction. 2013;108:1700-3.

6. Nita A, Neagu C, Stanciu S, Moisa C, Tit D. Study on the rate of consumption of new psychoactive substances. An Univ Oradea Fasc Biol. 2015;15:363-71.

7. Fletcher EH, Tasker SM, Easton P, Denvir L. Improving the help and support provided to people who take new psychoactive substances ('legal highs'). J Public Health. 2016;3:489-95. ulation surveys [22]. To look at the problem of NPS use in all of its complexity and to achieve more effective prevention, motivation for NPS use should also be explored and different motives for NPS use in terms of drug groups identified.

\section{Acknowledgments}

None

\section{Conflict of interest}

None to declare
8. Jerry J, Collins G, Streem D. Synthetic legal intoxicating drugs: The emerging 'incense' and 'bath salt' phenomenon. Cleve Clin J Med. 2012;79:258-64.

9. Castaneto MS, Gorelick DA, Desrosiers NA, Hartman RL, Pirard S, Huestis MA. Synthetic cannabinoids: Epidemiology, pharmacodynamics, and clinical implications. Drug Alcohol Depend. 2014;144:12-41.

10. Papanti D, Schifano F, Botteon G, Bertossi F, Mannix J, Vidoni D et al. 'Spiceophrenia': A systematic overview of 'spice'-related psychopathological issues and a case report. Human Psychopharmacol. 2013;28:379-89.

11. European Monitoring Centre for Drugs and Drug Addiction. European Drug Report 2017: Trends and Developments. Luxembourg: Publications Office of the European Union; 2017.

12. United Nations Office on Drugs and Crime. World Drug Report 2017. Vienna: United Nations publications; 2017.

13. European Monitoring Centre for Drugs and Drug Addiction. Perspectives on drugs: Legal approaches to controlling new psychoactive substances [Internet]. 2016 [cited 2017 June 23]. Available from: emcdda.europa.eu/topics/pods/controlling-newpsychoactivesubstances

14. European Monitoring Centre for Drugs and Drug Addiction and Europol. EU Drug Markets Report: 
Strategic Overview. EMCDDA-Europol Joint publications. Luxembourg: Publications Office of the European Union; 2016.

15. European Monitoring Centre for Drugs and Drug Addiction. EMCDDA-Europol 2015 Annual Report on the implementation of Council Decision 2005/387/JHA. Implementation reports. Luxembourg: Publications Office of the European Union; 2016.

16. Jerković D. Izazovi novih psihoaktivnih tvari. [Challenges of new psychoactive substances] In Roviš D, editor. Izazovi izgradnje cjelovitog pristupa prevenciji ovisnosti te liječenju, resocijalizaciji i socijalnoj reintegraciji ovisnika u Republici Hrvatskoj: Analiza stanja i potreba te iskustava Primorsko-goranske županije. [Challenges of building a comprehensive approach to prevention of addiction, and treatment, re-socialization and social reintegration of addicts in the Republic of Croatia: Analysis of the situation, needs and experiences of Primorsko-goranska County.] Rijeka: Faculty of Medicine of the University of Rijeka and Public Health Institute of Primorsko-goranska County; 2015. p. 33-44.

17. Office for Combating Drugs Abuse of the Government of the Republic of Croatia. Izvješće o provedbi nacionalne strategije i akcijskog plana suzbijanja zlouporabe droga za 2015. godinu. [Report on implementation of the national strategy and action plan for combating drug abuse for 2015] Zagreb: Office for Combating Drugs Abuse of the Government of the Republic of Croatia; 2016.

18. List of drugs, psychotropic substances, and plants used to produce drugs and substances that can be used in the production of drugs, Official Gazette; 10/2016

19. European Commission. Young people and drugs. Brussels: Flash Eurobarometer 401 - TNS Opinion \& Social; 2014.

20. European School Survey Project on Alcohol and Other Drugs. ESPAD Report 2015: Results from the European School Survey Project on Alcohol and Other Drugs. Luxembourg: Publications Office of the European Union; 2016.

21. Glavak Tkalić R, Miletić G-M, Maričić J. Uporaba sredstava ovisnosti u hrvatskom društvu: Istraživanje na općoj populaciji. [Substance use in Croatian society: Study among the general popu- lation.] Zagreb, Institut društvenih znanosti Ivo Pilar i Ured za suzbijanje droga Vlade Republike Hrvatske; 2016.

22. European Monitoring Centre for Drugs and Drug Addiction. Handbook for surveys on drug use among the general population. EMCDDA project CT.99.EP.08 B, Lisbon: European Monitoring Centre for Drugs and Drug Addiction; 2002.

23. European Monitoring Centre for Drugs and Drug Addiction. Country Drug Reports 2017. [Internet]. 2017 [cited 2017 June 23]. Available from:http:// www.emcdda.europa.eu/countries

24. European Monitoring Centre for Drugs and Drug Addiction. European Drug Report 2016: Trends and Developments. Luxembourg: Publications Office of the European Union; 2016.

25. Winstock A, Barratt M, Ferris J, Maier L. Global Drug Survey 2017. London: Global Drug Survey; 2017.

26. Sumnall HR, McVeigh J, Evans-Brown M. Epidemiology of use of NPS. In Dargen PI, Wood DM, editors. Novel psychoactive substances: Classification, pharmacology and toxicology. London: Academic Press; 2013. p. 79-104.

27. Baumann MH, Partilla JS, Lehner KR. Psychoact ive "bath salts": Not so soothing. Eur J Pharmacol. 2013; 698:1-5.

28. Karila L, Billieux J, Benyamina A, Lancon Rs Cottencin $\mathrm{O}$. The effects and risks associated to mephedrone and methylone in humans: A review of the preliminary evidences. Brain Res Bull. 2016;126:61-7.

29. Miotto K, Striebel J, Cho AK, Wang C. Clinical and pharmacological aspects of bath salt use: A review of the literature and case reports. Drug $\mathrm{Al}$ cohol Depend. 2013;132(1-2):1-12.

30. Sande, M. Characteristics of the use of 3-MMC and other new psychoactive drugs in Slovenia, and the perceived problems experienced by users. Int J Drug Policy. 2016;27:65-73.

31. Khaled SM, Hughes E, Bressington D, Zolezzi M, Radwan A, Badnapurkar A, et. al. The prevalence of novel psychoactive substances (NPS) use in non-clinical populations: A systematic review protocol. Syst Rev. 2016;5:195.

32. European Monitoring Centre for Drugs and Drug Addiction. High-risk drug use and new psychoactive substances: Results from an EMCDDA 
trendspotter study. Luxembourg: Publications Office of the European Union; 2017.

33. Van Amsterdam JG, Nabben T, Keiman D, Haanschoten G, Korf D. Exploring the attractiveness of New Psychoactive Substances (NPS) among experienced drug Users. J Psychoactive Drugs. 2015;47:177-81.
34. Abdulrahim D, Whiteley C, Moncrieff M, BowdenJones O. Club Drug Use Among Lesbian, Gay, Bisexual and Trans (LGBT) People. Novel Psychoactive Treatment UK Network (NEPTUNE). London; 2016.

\section{Uporaba novih psihoaktivnih tvari u općoj populaciji Republike Hrvatske: obrasci uporabe i sociodemografske karakteristike konzumenata}

Sažetak - Cilj istraživanja bio je prikupiti podatke o prevalenciji uporabe novih psihoaktivnih tvari (NPT) u općoj populaciji Republike Hrvatske, o obrascima uporabe NPT-a i karakteristikama konzumenata NPT-a. Podaci o uporabi NTP-a, o obrascima uporabe NTP-a, o uporabi legalnih i ilegalnih droga te sociodemografski podaci o sudionicima prikupljeni su empirijskim istraživanjem na reprezentativnom uzorku građana Republike Hrvatske u dobi od 15 do 64 godine ( $N=4992)$. Životna prevalencija uporabe NPT-a u Hrvatskoj bila je 2,7\%, a prevalencija uporabe u posljednjih godinu dana 1,3\%. Najčešće korišten oblik NPT-a bile su biljne mješavine za pušenje (76,2\%), a većina konzumenata dobila je ili kupila NPT od prijatelja (69\%). Većina konzumenata NPT-a bili su muškarci $(75,4 \%)$, mlađi odrasli u dobi od 15 do 34 godine $(75,8 \%)$, samci (73,1\%), oni sa završenom srednjom školom (68\%), oni koji polaze srednju školu ili su studenti (39,4\%), zaposleni (33,1\%) ili samozaposleni (7,2\%). Konzumenti NPT-a navode vrlo visoku prevalenciju uporabe legalnih (79,5\% duhan, 89,9\% alkohol, dok se 57,5\% opijalo) i ilegalnih droga (55,6\%, najčešće kanabisa) u mjesecu koji je prethodio istraživanju. Visoka životna prevalencija uporabe ilegalnih droga utvrđena je za amfetamine (42,5\%), ecstacy $(35,4 \%)$ i kokain $(23,9 \%)$. Zaključno, životna prevalencija uporabe NPT-a među općom populacijom u Hrvatskoj relativno je niska. Većina konzumenata NPT-a su mladi muškarci, samci, koji iskazuju obrasce poliuporabe droga. Zbog ozbiljnih rizika povezanih s uporabom NPT-a, prevencija bi trebala biti jedan od prioriteta nacionalne politike vezane uz droge.

Ključne riječi: nove psihoaktivne tvari, prevalencija, obrasci uporabe, opća populacija, Hrvatska 